\title{
Semen Characteristics of Yankasa Rams Following Cypermethrin Treatment
}

\section{Ubah Simon Azubuike ${ }^{1, *}$, Ogwu David ${ }^{2}$, Rekwot Peter Ibrahim², Rwuaan Joseph Sankey ${ }^{2}$, Chibuogwu Ijeoma Chika ${ }^{3}$, Enem Simon Ikechukwu ${ }^{4}$}

\author{
${ }^{1}$ Department of Theriogenology, Faculty of Veterinary Medicine, University of Abuja, Federal Capital Territory, Nigeria \\ ${ }^{2}$ Department of Theriogenology and Production, Ahmadu Bello University Zaria, Kaduna State, Nigeria \\ ${ }^{3}$ Animal Science Department, Faculty of Agriculture, University of Abuja, Federal Capital Territory, Nigeria \\ ${ }^{4}$ Department of Veterinary Public Health, Faculty of Veterinary Medicine, University of Abuja, Federal Capital Territory Nigeria
}

\section{Email address:}

drubah2000@yahoo.com (U. S. Azubuike),daveogwu@yahoo.com (O. David), bankwa2006@yahoo.com (R. P. Ibrahim), josephrwuaan@yahoo.com (R. J. Sankey), ije.chibu@yahoo.com (C. I. Chika), enemsimon@yahoo.com (E. S. Ikechukwu) ${ }^{*}$ Corresponding author

\section{To cite this article:}

Ubah Simon Azubuike, Ogwu David, Rekwot Peter Ibrahim, Rwuaan Joseph Sankey, Chibuogwu Ijeoma Chika, Enem Simon Ikechukwu. Semen Characteristics of Yankasa Rams Following Cypermethrin Treatment.European Journal of Clinical and Biomedical Sciences. Vol. 3, No. 3, 2017, pp. 53-58. doi: 10.11648/j.ejcbs.20170303.11

Received: October 5, 2016; Accepted: November 11, 2016; Published: May 6, 2017

\begin{abstract}
This work was aimed to assess the semen characteristics of Yankasa rams following Cypermethrin treatment. Cypermethrin was used topically at the dose rate of $3 \mathrm{mg} / \mathrm{kg}$ b.w $(0.1 \mathrm{ml} / \mathrm{kg})$. Sixteen healthy Yankasa rams and weighing between $21.5 \mathrm{~kg}$ and $43 \mathrm{~kg}$ and between the ages of 18 and 30 months were used. The animals were divided into groups A and B. Group A was given 3\% Cypermethrin as pour-on fortnightly for a period of twelve weeks. Group B was given distilled water at the same rate $(0.1 \mathrm{ml} / \mathrm{kg})$, route of administration and period. Semen samples were collected weekly by the use of a battery powered hand held electro ejaculator. Results showed that Cypermethrin significantly reduced mean sperm concentration, motility, viability, semen volume and $\mathrm{pH}$ of Yankasa rams. The difference between the mean sperm motility of groups A and B in weeks 6,7 and 8 were statistically significant $(\mathrm{P}<0.05)$. The values were $37.78 \pm 5.21 \%$ and $82.11 \pm 9.12 \%, 22.86 \pm 4.10 \%$ and $73.42 \pm 8.07 \%$, $32.14 \pm 10.17$ and $67.86 \pm 9.31 \%$ for groups A and B respectively. Semen volume was significantly higher in control rams at week $2(\mathrm{P}<0.05)$. The values were $0.36 \pm 0.04 \mathrm{ml}$ and $0.93 \pm 0.26$ mlfor groups $\mathrm{A}$ and $\mathrm{B}$ respectively. The difference between the mean sperm concentration of groups A and B were statistically significant in weeks 5 and $7(\mathrm{P}<0.05)$. The mean sperm concentrations of groups A and B were $3190 \pm 499.76 \times 10^{6} / \mathrm{ml}$ and $4558 \pm 558.10 \times 10^{6} / \mathrm{ml}, 1931 \pm 102.57 \times 10^{6} / \mathrm{ml}$ and $3300 \pm 309.15 \times 10^{6} / \mathrm{ml}$ for weeks 5 and 7 respectively. The difference between the mean percentage live of groups A and B were statistically significant in weeks 6,7 and $8(\mathrm{P}<0.05)$. The values were $45.55 \pm 4.75 \%$ and $82.22 \pm 7.78 \%$ in week $6,48.57 \pm 5.95 \%$ and $84.29 \pm 3.69 \%$ in week 7, $47.14 \pm 9.44$ and $74.29 \pm 3.69 \%$ in week 8 for groups A and B respectively. By week 12 of the experiment, the mean semen $\mathrm{pH}$ values $6.60 \pm 0.10$ and $8.00 \pm 0.09$ for groups $\mathrm{A}$ and $\mathrm{B}$ respectively were significantly different $(\mathrm{P}<0.05)$.It was concluded that Cypermethrin lowers semen quality of Yankasa rams. It was therefore, recommended that Cypermethrin be used with caution inrams and further studies on the meat residue be done for public health concern.
\end{abstract}

Keywords: Semen, Characteristics, Cypermethrin, Yankasa, Rams

\section{Introduction}

Yankasa sheep have an important role in alleviating the problem of animal protein deficiency in Nigeria, because they are the most numerous and most widely distributed among the 22.3 million indigenous sheep population in Nigeria [1]. They are kept for meat and are estimated to constitute $60 \%$ of the livestock population in Nigeria [2]. Livestock have been reported to provide only $20 \%$ of human protein consumption in developing countries [3]. Reproduction is one of the most important factors affecting livestock production [4]. As in other tropical areas, productivity of the livestock population in Nigeria has been hampered by the low fertility of the breeding herd amongst other factors [5]. It is well documented that 
Cypermethrin affects the male reproductive performance in many species $[6 ; 7 ; 8 ; 9 ; 10 ; 11$ and 12$]$. It is used in Veterinary practice against ectoparasites [13]. Cypermethrin is toxic not only for insects but also for mammals [14;15]. Most products in our markets today for control of ectoparasitesin animals contain Cypermethrin [13]. Cypermethrin is an insecticide in the synthetic pyrethroid family. All of the insecticides in this family have chemical structures that are loosely based on pyrethrins which are insecticidal compounds found in chrysanthemum flowers. Most synthetic pyrethroids are complex molecules, Cypermethrin is no exception. Because of its complexity, there are eight different ways that the atoms that make up the Cypermethrin molecules can arrange themselves in three dimensions. These are called isomers; Cypermethrin is a mixture of all eight isomers [6].

In animals, Cypermethrin has been used as a chemotherapeutic agent against ectoparasite infestations [10]. There have been reports of lowered reproductive functions in experimental animals exposed to this chemical $[6 ; 8 ; 9 ; 0]$. Scanty work has been documented on the semen characteristics of our domestic ruminants exposed to this chemical. Semen quality is a major indicator of fertility of male animals. This study was designed to investigate semen characteristics of Yankasa rams treated with Cypermethrin with the following objectives, (1) toassess semen characteristics of Yankasa rams treated with Cypermethrin. (2) To determine the Semen $\mathrm{pH}$ of Yankasa rams treated with Cypermethrin.

\section{Materials and Methods}

\subsection{Study Location}

The research was carried out at the National Animal Production Research Institute (NAPRI) Shika, Ahmadu Bello University Zaria, which is situated in the Northern Guinea Savannah and lying between latitudes $11^{\circ}$ and $12^{\circ} \mathrm{N}$ and between longitude $7^{\circ}$ and $8^{\circ} \mathrm{E}$ at an elevation of $650 \mathrm{~m}$ above sea level. The area has an annual rainfall of $1100 \mathrm{~mm}$. [16]. There are two seasons rainy season (May-October) and dry season (November-April) [13].

\subsection{Experimental Animals}

Sixteen sexually-mature, healthy Yankasa rams aged 18-30 months and weighing between $21.5 \mathrm{~kg}-46.5 \mathrm{~kg}$ with clinically normal genitalia were used. The rams were purchased from the open market in Sabua Local Government Area of Katsina State, they were acclimatized for two weeks at the Small Ruminant Research Unit of NAPRI, after which they were judged to be in good health based on clinical findings, hematological and fecal examinations. The rams were housed at the Small Ruminant Research Unit of NAPRI (The house was made of brick concrete pens with concrete floors. The rams were divided into two groups of eight rams each. They were given concentrate feed ad-libitum (cotton seed, maize offal, maize, wheat offal, bone meal and salt) in the morning and later in the evening; hay was made available during the day at intervals. The hay used was Digitariasimuthii andwater was given ad-libitum.

\subsection{Experimental Design and Treatment}

The rams were divided into groups $\mathrm{A}$ and $\mathrm{B}$, where $\mathrm{A}$ was the treated group and B the control group of eight rams each for the study. The animals were acclimatized for two weeks during which blood and fecal samples were collected and analyzed for haemoparasites and helminthes and treatments were given where necessary.

Administration of 3\% Cypermethrin

The rams in group (A) were administered Cypermethrin $3 \%$ at the dose rate of $3 \mathrm{mg} / \mathrm{kg}(0.1 \mathrm{ml} / \mathrm{kg})$ body weight, topically as pour-on. The control group (B) were administered distilled water at the same rate of $0.1 \mathrm{ml} / \mathrm{kg}$ body weight topically as pour-on. These treatments were repeated every two weeks for a period of 12 weeks. Samples of semen were collected before the administration of $3 \%$ Cypermethrin to establish base line data, thereafter semen samples were collected weekly.

\subsection{Semen Collection and Evaluation}

Semen was collected on weekly basis from each ram during the experiment by means of a hand held ElectroEjaculator (EE). The electro-ejaculator consists of a bipolar electrode and variable source of alternating electric current.

Semen collections were done in the morning between 8:00am and 10:00am once every week. Before semen collection, the animals were adequately restrained and the prepuce disinfected using $4.8 \%$ chloroxynol (Detol ${ }^{\circledR}$ diluted with water prior to the rectal insertion of the probe, the electrode was lubricated with petroleum $\left(\mathrm{KY}^{\mathbb{B}}\right)$ jelly to ease insertion. The lubricated probe of the electro-ejaculator (Electrojet $^{\circledR}$, Electrovet, Sao Paulo, Brazil) was then inserted into the rectum and switched on to produce an erection, and subsequently ejaculation by using the manual button of the instrument, the power output was switched on by pressing and holding for 2 to 3 seconds. The power output was again pressed to cut off the output. This procedure was repeated after a rest period, equal to the duration of electrical stimulation, by increasing the duration of power output by one second on every attempt until ejaculation takes place. The urethral process and end of the penis was held in a semen collection tube for the ejaculate to be collected. Semen was collected in graduated plastic tubes for evaluation.

\subsection{Semen Examination and Evaluation}

Semen quality parameters that were quantified weekly, were semen volume $(\mathrm{ml})$, semen colour, semen $\mathrm{pH}$, sperm concentration $\left(\times 10^{6} / \mathrm{ml}\right)$, sperm motility $(\%)$, percentage live (\%) as well as morphological defects (\%).

\subsubsection{Gross Examination}

The procedure used for evaluation of semen quality traits was that described by [17]. Ejaculated semen was collected in calibrated glass tube and the volumeand colour were immediately recorded before the tube was placed in a water 
bath at $37^{\circ} \mathrm{C}$. The colour was read from the graduated collecting tube, for colour determination, a score of 4,3 and 2 was used for creamy, milky and watery/colourless respectively. The $\mathrm{pH}$ was determined using $\mathrm{pH}$-indicator strips (Neutralit ${ }^{\circledR}$, merck, Bucharest, Romania). Gross sperm motility was assessed immediately by examining a drop of raw undiluted semen on a pre-warmed slide under a field microscope at the magnification of x 10 [18]. Semen motility was graded from 0 $100 \%$ (0-20 very poor, $20-40$ poor, $40-50$ fair, 50-80 good, 80 90 very good and 90-100 excellent) with 100 forthose that showed rectilineal movement and wave pattern. Sperm concentration was determined using the improved Neubauerhaemocytometer after dilution in $0.05 \%$ formalsaline.

\subsubsection{Microscopic Examination}

Sperm morphology was determined by methods described by [19]. The percentage live sperm and morphological sperm abnormalities/defects were determined by examining semen smears stained with eosin-nigrosin on a glass slide [20;21]. Sperm abnormalities were classified as described by Blom (1972) [22]. The live-dead staining principle was based upon the observation that eosin B penetrates and stains the dead sperms whereas the viable cells repel the stain. The staining mixture consisted of $1 \%$ eosin $\mathrm{B}$ and $5 \%$ of nigrosin in $3 \%$ sodium citrate dehydrate solution. One drop of raw semen was added to one drop of the stain, it was mixed thoroughly and a fresh smear was made from it. The slide was then examined under high power (x 100) and at least 100 cells (both stained and unstained) were counted and a percentage of each was estimated.

\subsection{Statistical Analysis of Data}

Data was expressed as means and Standard Error of Mean (SEM). Data was analyzed using descriptive statistics and paired student's t-test with SPSS/PC computer program (Version 20.0, SPSS $^{\circledR}$, Chicago IL, USA). Differences with confidence values of $\mathrm{p}<0.05$ were considered statistically significant [23].

\section{Results}

\section{Semen Characteristics}

Table 1. Base line data for semen characteristics in both the treated and control rams. (Mean \pm SEM).

\begin{tabular}{lll}
\hline Parameters & Treated & Control \\
\hline & $\mathbf{n = 8}$ & $\mathbf{n = 8}$ \\
\hline Semen Colour & $3.5 \pm 0.00$ & $3.75 \pm 0.00$ \\
Semen Volume $(\mathrm{ml})$ & $1.20 \pm 0.18$ & $0.73 \pm 0.08$ \\
Concentration $\left(\mathrm{x} 10^{6}\right) / \mathrm{ml}$ & $3230.25 \pm 49.1$ & $3850.38 \pm 38.98$ \\
Percentage live $(\%)$ & $80.00 \pm 8.6$ & $87.50 \pm 1.64$ \\
Gross sperm motility $(\%)$ & $61.88 \pm 8.96$ & $66.25 \pm 4.60$ \\
Sperm (abnormal) $(\%)$ & $14.00 \pm 1.58$ & $13.13 \pm 1.37$ \\
Semen pH & $7.00 \pm 0.00$ & $7.00 \pm 0.00$ \\
\hline
\end{tabular}

\section{i. Sperm Motility}

The mean weekly sperm motility of the treated and control groups are presented (Table 2).
Table 2. Weekly sperm motility (\%) of Yankasa rams during treatmentperiod (Mean \pm SEM).

\begin{tabular}{lll}
\hline Weeks & Treated & Control \\
\hline & $\mathbf{n = 8}$ & $\mathbf{n}=\mathbf{8}$ \\
\hline 1 & $63.00 \pm 7.12$ & $68.00 \pm 9.50$ \\
2 & $78.40 \pm 9.50$ & $64.40 \pm 11.40$ \\
3 & $86.60 \pm 4.42$ & $70.40 \pm 10.20$ \\
4 & $80.00 \pm 8.43$ & $84.90 \pm 4.37$ \\
5 & $64.50 \pm 6.43$ & $79.20 \pm 8.79$ \\
6 & $37.78 \pm 5.21^{\mathrm{a}}$ & $82.11 \pm 9.11^{\mathrm{b}}$ \\
7 & $22.86 \pm 4.10^{\mathrm{a}}$ & $73.42 \pm 8.07^{\mathrm{b}}$ \\
8 & $32.14 \pm 10.17^{\mathrm{a}}$ & $67.86 \pm 9.31^{\mathrm{b}}$ \\
9 & $20.00 \pm 5.23$ & $40.00 \pm 13.50$ \\
10 & $21.71 \pm 4.46$ & $37.14 \pm 17.22$ \\
11 & $29.29 \pm 4.42$ & $39.14 \pm 5.55$ \\
12 & $25.71 \pm 8.41$ & $41.57 \pm 7.13$ \\
\hline
\end{tabular}

(a b) Means in the same row with different superscript alphabet are statistically significant $(\mathrm{P}<0.05)$.

\section{ii. Semen volume}

The mean weekly semen volume of the treated and control groups is presented in (Table 3 ).

Table 3. Weekly semen volume $(\mathrm{ml})$ of Yankasa rams during treatment period (Mean $\pm S E M)$.

\begin{tabular}{lll}
\hline Weeks & Treated & Control \\
\hline & $\mathbf{n = 8}$ & $\mathbf{n = 8}$ \\
\hline 1 & $0.90 \pm 0.20$ & $0.70 \pm 0.13$ \\
2 & $0.36 \pm 0.04^{\mathrm{a}}$ & $0.93 \pm 0.26^{\mathrm{b}}$ \\
3 & $0.81 \pm 0.16$ & $0.40 \pm 0.07$ \\
4 & $0.71 \pm 0.15$ & $0.77 \pm 0.19$ \\
5 & $0.70 \pm 0.14$ & $0.85 \pm 6.12$ \\
6 & $0.89 \pm 0.19$ & $0.67 \pm 0.17$ \\
7 & $0.83 \pm 0.11$ & $0.74 \pm 0.19$ \\
8 & $0.78 \pm 0.22$ & $0.55 \pm 0.10$ \\
9 & $0.81 \pm 0.17$ & $0.68 \pm 0.16$ \\
10 & $0.31 \pm 0.06$ & $0.29 \pm 0.07$ \\
11 & $0.31 \pm 0.06$ & $0.25 \pm 0.52$ \\
12 & $0.51 \pm 0.08$ & $0.50 \pm 0.21$ \\
\hline
\end{tabular}

(a b) Means in the same row with different superscript alphabet are statistically significant $(\mathrm{P}<0.05)$.

\section{iii. Semen Concentration}

The mean weekly semen concentration of the experimental and control groups are presented(Table 4).

Table 4. Weekly sperm concentration $\left(x 10^{6} / \mathrm{ml}\right)$ of Yankasa during the treatment period(Mean \pm SEM).

\begin{tabular}{lll}
\hline Weeks & Treated & Control \\
\hline & $\mathbf{n = 8}$ & $\mathbf{n = 8}$ \\
\hline 1 & $3769 \pm 690.0$ & $3958 \pm 420.0$ \\
2 & $2560 \pm 290.0$ & $2843 \pm 450.0$ \\
3 & $3637 \pm 300.98$ & $3082 \pm 224.75$ \\
4 & $3719 \pm 239.85$ & $4190 \pm 268.22$ \\
5 & $3190 \pm 499.76^{\mathrm{a}}$ & $4558 \pm 558.10^{\mathrm{b}}$ \\
6 & $2296 \pm 480.45$ & $2979 \pm 543.83$ \\
7 & $1931 \pm 102.57^{\mathrm{a}}$ & $3300 \pm 309.15^{\mathrm{b}}$ \\
8 & $2517 \pm 191.30$ & $3419 \pm 283.41$ \\
9 & $2054 \pm 187.08$ & $2891 \pm 412.30$ \\
10 & $1957 \pm 412.81$ & $1661 \pm 585.42$ \\
11 & $1957 \pm 730.72$ & $1724 \pm 819.90$ \\
12 & $2013 \pm 333.52$ & $2641 \pm 373.50$ \\
\hline
\end{tabular}

(a b) Means in the same row with different superscript alphabet are statistically significant $(\mathrm{P}<0.05)$. 


\subsubsection{Percentage live}

The mean weekly percentage live of the treated and control groups are presented(Table 5).

Table 5. Weekly percentage live (\%) of Yankasa rams during the treatment period (Mean \pm SEM).

\begin{tabular}{lll}
\hline Weeks & Treated & Control \\
\hline & $\mathbf{n = 8}$ & $\mathbf{n = 8}$ \\
\hline 1 & $82.00 \pm 4.20$ & $83.00 \pm 3.00$ \\
2 & $82.00 \pm 5.92$ & $85.00 \pm 1.67$ \\
3 & $81.00 \pm 2.77$ & $81.00 \pm 6.05$ \\
4 & $79.00 \pm 5.86$ & $84.00 \pm 2.67$ \\
5 & $74.00 \pm 4.76$ & $82.00 \pm 5.12$ \\
6 & $45.55 \pm 4.75^{\mathrm{a}}$ & $82.22 \pm 7.78^{\mathrm{b}}$ \\
7 & $48.57 \pm 5.95^{\mathrm{a}}$ & $84.29 \pm 3.69^{\mathrm{b}}$ \\
8 & $47.14 \pm 9.44^{\mathrm{a}}$ & $74.29 \pm 3.69^{\mathrm{b}}$ \\
9 & $27.14 \pm 5.22$ & $45.71 \pm 12.70$ \\
10 & $28.00 \pm 7.35$ & $30.00 \pm 17.61$ \\
11 & $23.86 \pm 6.06$ & $37.14 \pm 9.93$ \\
12 & $41.71 \pm 11.64$ & $50.57 \pm 0.00$ \\
\hline
\end{tabular}

(a b) Means in the same row with different superscript alphabet are statistically significant $(\mathrm{P}<0.05)$.

\section{iv. Sperm Morphology (\% Abnormality)}

The mean weekly sperm abnormalities of the treated and control groups are presented in (Fig.1). (P>0.05)

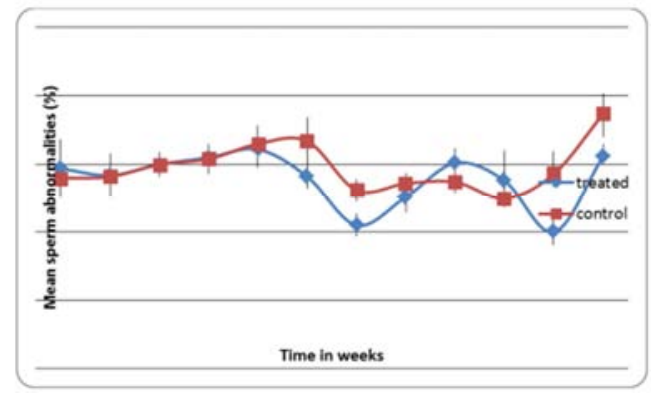

Figure 1. Mean weekly total sperm abnormalities (\%) of Yankasa rams during the treatment period.

\section{v. Semen colour}

Table 6. Weekly mean values of semen colour of Yankasa rams during the treatment Period (Mean \pm SEM).

\begin{tabular}{lll}
\hline Week & treated & Control \\
\hline & $\mathbf{n = 8}$ & $\mathbf{n = 8}$ \\
\hline 1 & $3.70 \pm 0.15$ & $3.30 \pm 0.21$ \\
2 & $3.70 \pm 0.21$ & $3.80 \pm 0.13$ \\
3 & $3.70 \pm 0.15$ & $3.80 \pm 0.13$ \\
4 & $3.70 \pm 0.21$ & $3.70 \pm 0.15$ \\
5 & $3.40 \pm 0.22$ & $3.80 \pm 0.13$ \\
6 & $3.00 \pm 0.21$ & $3.20 \pm 0.25$ \\
7 & $3.43 \pm 0.37$ & $3.30 \pm 0.26$ \\
8 & $3.14 \pm 0.34$ & $3.20 \pm 0.29$ \\
9 & $2.86 \pm 0.34$ & $3.10 \pm 0.23$ \\
10 & $2.27 \pm 0.37$ & $2.30 \pm 0.15$ \\
11 & $2.57 \pm 0.37$ & $2.40 \pm 0.22$ \\
12 & $3.14 \pm 0.34$ & $3.40 \pm 0.22$ \\
\hline
\end{tabular}

Key: colour=assigned value

Creamy $=4$

Milky $=3$

Watery $=2$
The mean weekly semen colour of treated and control groups are presented (Table 6).

\section{vi. Semen $\mathrm{Ph}$}

The mean weekly semen $\mathrm{pH}$ of both the treated and control groups are presented (Fig. 2). By week 12 of the experiment, the mean $\mathrm{pH}$ values for the treated and the control groups were $6.60 \pm 0.10^{\mathrm{a}}$ and $8.00 \pm 0.09^{\mathrm{b}}$. The difference was statistically significant $(\mathrm{P}<0.05)$.

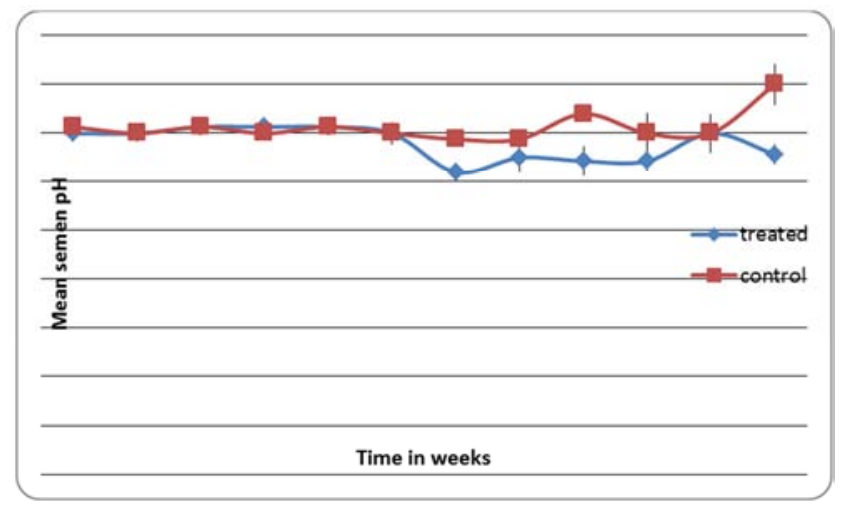

Figure 2. Mean weekly semen $p H$ of Yankasa rams during the treatment period.

\section{Discussion}

The present study indicates that Cypermethrin at the dose of $3 \mathrm{mg} / \mathrm{kg}$ body weight has adverse effects on some semen characteristics of Yankasa rams. The study showed that percentage live, sperm concentration, semen volume as well as percentage motility were significantly reduced during the treatment period. In contrast, percentage abnormality and colour were not significantly affected. According to our result, virtually all the parameters of semen characteristics decreased from their initial values and this was in resonance with semen samples collected by electro-ejaculation. One of the problems of samples collected by electro-ejaculation is that volume, motility and density are not necessarily representative and electro-ejaculation is generally well tolerated [24]. This buttresses the fact that electro-ejaculation is a stressful procedure in rams. Therefore, the semen characteristics studied in this case decreased from their initial values except percentage abnormalities which increased. However, during the experiment, there was a statistically significant difference between sperm concentration, percentage live, sperm motility and semen volume of the treated and control rams, whereas, there was no statistically significant difference between the semen percentage abnormalities. A similar report have also been made by [11]. In laboratory animals, previous studies showed that Cypermethrin was able to influence some reproductive and fertility parameters as exposure to this chemical can cause significant increase in the production of nonviable or abnormal sperm in mice [11]. Cypermethrin decreases the weight of testosterone-sensitive organs, increases the height of seminal gland epithelium and reduces sperm count and motility in mice. [10]. All doses of $1 \mathrm{mg} / \mathrm{kg}, 10 \mathrm{mg} / \mathrm{kg}$ and 
high dose $20 \mathrm{mg} / \mathrm{kg}$ beta Cypermethrin used in a 36 day experiment decreased sperm count, viability and intact acrosome rate. [10]. A significant increase in the proportion of dead and abnormal sperms in mice exposed to Cypermethrin has been reported [25]. After 4 and 8 weeks beside that sperm motility percentage was affected sperm concentration were found to be significantly decreased after 2, 4 and 8 weeks of exposure [26]. Studies on the effects of oral administration of two synthetic pyrethroid insecticides. Sumcidine and 5-3206 on male mature rats at doses of 20, 100,1 and $5 \mathrm{mg} / \mathrm{kg}$ body weight respectively for 65 successive days showed that pyrethriod insecticides caused significant decrease in the weights of male reproductive organs, sperm cell count, percentage of sperm motility and seminiferous tubules containing spermatozoa as well as significant increase in the percentage of sperm head and tail abnormalities [27]. The above cited reports agree with the findings of our studies in relation to semen concentration, sperm motility and viability, but not with percentage abnormality. The detrimental effect of Cypermethrin on semen characteristics of Yankasa rams may also pose a public health threat, as Cypermethrin is found in large amounts in body fat. Therefore, residues in exposed animals may gain access to human population through meat and milk products. This is supported by the report that pesticide exposure is associated with infertility. There is much concern that exposure to environmental contaminants causes decreased sperm counts, impairment of sperm motility, reduced fertilization ability, producing abnormal sperm in men and wildlife [28]. In the current studies using Yankasa rams at a dose of $3 \mathrm{mg} / \mathrm{kg}$ as applied in field practice in ruminants, Cypermethrin exerted almost the same negative impact on semen characteristics of the experimental rams. Just as it affects semen characteristics of laboratory animals which have been widely reported [6;10 and 11].

Besides, the parameters that have been frequently reported as being affected by Cypermethrin, our studies also showed that Cypermethrin significantly affected the semen $\mathrm{pH}$. Thus, semen from rams exposed to Cypermethrin is likely to become acidic. The changes observed in semen colour pattern weekly was common to both the treated and control rams, and decreasing value of semen colour over the period of the experiment may be attributed to the method of collection i.e. electro-ejaculation as well as frequency of collection i.e weekly. But there was no statistically significant difference between the colour value of the treated and control rams during the treatment period.

\section{Conclusion}

Based on the findings of this research it was concluded that application of 3\% Cypermethrin as pour-on at the dose of $3 \mathrm{mg} / \mathrm{kg}$ body weight fortnightly for a period of 12 weeks significantly reduced sperm concentration, percentage live, sperm motility, semen volume and semen $\mathrm{pH}$ of treated rams. Such treatments have no effects on percentage sperm abnormality and semen colour. It was recommended that the use of $3 \%$ Cypermethrin at the dose of $3 \mathrm{mg} / \mathrm{kg}$ in rams be applied with caution as it may affect semen quality and fertility of the rams, further studies on the meat residue of Cypermethrin be carried for public health concern as regards male fertility.

\section{References}

[1] FDLPCS. (1991). Nigerian national livestock survey. Federal Department of Livestock and Pest Control Services, Abuja Vol. 2.80.

[2] Afolayan, R, A., Adeyinka, I. A and Lakpini, C. A. M. (2006). The estimation oflive weight from body measurements in Yankasa sheep. Czech Journal, 51 (8): 343-348.

[3] FAO. (1983). Food production trends in Africa. Food and Agricultural Organisation of the United Nations. Rome.

[4] Rasbech, N. O. (1984). The male and fertility of domestic animals. In: The Male In Farm Animal Reproduction. Courot, M (ed). Pp. 2-23.

[5] Payne, W. J. A and Wilson, R. T. (1999). An Introduction to Animal Husbandry inthe Tropics. Blackwell Science Ltd., Pp. 447-484.

[6] Caroline, C. (1996). Insecticide fact sheet. Journal of Pesticide Reform/Summer Vol. 16, No 2.

[7] Lakkawar, A. W., Chattopadhway, S. K and Som Vanshi, R. (2004). Experimental Cypermethrin toxicity in rabbits-A Clinical and Patho-Anatomical Study. Folia Veterinaria 48 1:3-8.

[8] Assayed, M. E., H. A, Salem and Khalaf, A. A. (2008). Protective effects of garlicextract and vitamin $\mathrm{C}$ against Cypermethrin reproductive toxicity in male rats. Research Journal of Vet. Science, 1:1-5.

[9] Ling, S., Yu-Bang, W., Hong, S., Chen, Y., Xia, H., Jian-Hua, Q., Jian-wei, Z andXin-Ru, W. (2008). Effects of Fenvalerate and Cypermethrin on rat sperm motility patterns in vitro as measured by computer assisted sperm analysis. Journal of Toxicology and Environmental Health ParthA. Volume 71, (5) Pp. 325-332.

[10] Wang, X-Z., Liu, S-S., Sun., Wu, J-Y., Zhou, Y-L and Zhang, J-H. (2009). $\beta$-Cypermethrin impairs reproductive function in male mice by inducing oxidative stress. Theriogenology, 72, 599-611.

[11] Jalal, S., Ramin, H and Roohollah, T. Z. (2010). Effect of Cypermethrin on sexual behaviour and plasma concentrations of pituitary gonadal hormones. International Journal of Fertility and Sterility Vol. 4, No. 1, Pp. 23-28.

[12] Prakash, N., Kumar, V.M., Sunichandra, U., Pavithra, B.H and Pawar, A. (2010).Evaluation of testicular toxicity following short-term exposure to Cypermethrin in albino mice. Toxicol International. Society of Toxicology, 17:18-21.

[13] Ubah, S. A., Ogwu, D., Rekwot, P. I., Rwuaan, J. S and Chibuogwu, I. C (2016). Gonadal and epididymal sperm reserves of Yankasa rams treated with Cypermethrin. American Journal of Biomedical and Life Sciences 4(2) pp16-20.

[14] He, F. (2000). Neurotoxic effect of insecticides current and future research: Areview. Neurotoxicology, 21(5): 829-835. 
[15] Barlow, S. M., Sullivan, F. M and Lines, J. (2001). Risk assessment of the use of deltamethrin on bed nets for the prevention of malaria, Food and Chemical Toxicology, 39(5): 407-422.

[16] Igono, M., Molokwu, E. C. I and Aliu, Y. O. (1982). Body temperature responses of Savanah Brown goats to hamattan and hot-dry seasons. International Journal of Biometeorology, 26: $225-230$.

[17] Singh, K. P., Jouhari, D. C., Majumdar, S., Mohpatra, S. C and Thiyagasundaram, T. S. (1987). Evaluation of semen quality traits of White Leghorn selected for egg production. Indian Journal of Poultry Science, 22: 129-132.

[18] Rota, A., Stroma, B and Linde-Forberg, C. (1995). Effects of seminal plasma andthree extenders on canine semen stored at $4^{\circ} \mathrm{C}$. Theriogenology, 44:885-900.

[19] Zemjanis, R. (1970). Collection and evaluation of semen In: Diagnostic and Therapautic Technique in Animal Reproduction. $2^{\text {nd }}$ edition. The Williams and Wilkins Company, Baltimore.

[20] Vilakazi, D. M and Webb, E. C. (2004). Effect of age and season on spermMorphology of Friesland bulls at an artificial insemination center in South African. Journal of Animal Science, 34:62-69.

[21] Michael, A. J., Alexopoulos, C., Pontiki, E. A., HadjipavlouLitina, D. J., Saratsis, P. H., Ververidis, H.N and Boscos, C. M. (2008). Quality and reactive oxygen species of extended canine semen after vitamin C supplementation. Theriogenology, 70:827-835.

[22] Blom, E. (1972). The ultrastructure of some characteristic sperm defects and aproposal for a new classification of bull spermiogram. Ahi Del VII Sysposio International De Zootechnia, Milano. Pp. 125-139.

[23] Daniel, W. W. (1991). Analysis of variance. In: Daniel, W. W. (Ed), Biostatistic: A Foundation for Analysis in the Health Sciences. John Wiley \& Sons, Hoboken. Pp. 74-320.

[24] Timothy, J. P. (2009). Normal reproduction in male animals. In: David, E. N., Timothy, J. P and Garry, C. W (Ed). Veterinary Reproduction and Obstetrics $9^{\text {th }} \mathrm{Ed}$. Saunders Elsevier. Pp. 681-759.

[25] Bhunya, S. P and Pati, P. C. (1988). Genotoxic effects of synthetic pyrethroidinsecticide, Cypermethrin, in mice in vivo. Toxicology Letters, 41: 223-230.

[26] El-Ashmawy, I. N., Zakaria, A. D., Hemed, S. M. A., ElFikey, S. and Hussein, Y. A. (1993). Cytotoxic effects of the pyrethroid insecticide (Matox) with reference to its influence on the reproductive hormone. Veterinary Medical Journal. Giza, 3: 125-130.

[27] Hassan, A. B., Saliman, G. A., Farag, A. A and Sobbhy, H. M. (1993). Effect of the synthetic pyrethroidsSumicidin and S3206 on male rat fertility. Veterinary Medical Journal, Giza, 41: $33-38$

[28] Elbetieha, A. O., Da'as, S. I., Khamas, W and Darmani, H. (2001). Evaluation of the toxic Potentials of Cypermethrin pesticide on some reproductive and fertility parameters in the male rats. Archives of Environmental Contamination and Toxicology, 41(4): 522-528. 